\title{
Generation of Epstein-Barr Virus Immortalized-B Lymphocytes Cell Line of Orang Asli
}

\section{Mohd Helmy Yusof', Sharifah Izwan Tuan Othman², Siti Shuhada Mokhtar', Yushimah Yunus ${ }^{1}$, Abu Thalhah Abdul Aziz' and Hoh Boon Peng ${ }^{3 *}$}

${ }^{1}$ Institute of Medical Molecular Biotechnology (IMMB), Universiti Teknologi MARA (UiTM), Malaysia

${ }^{2}$ Biomedical \& Health Sciences, UNISEL, Malaysia

${ }^{3}$ Medicine and Health Sciences, UCSI University, Malaysia

*Corresponding author: Hoh Boon Peng, Faculty of Medicine and Health Sciences, UCSI University, Jalan Menara Gading, Cheras, 56000 Kuala Lumpur, Wilayah Persekutuan Kuala Lumpur, Malaysia, E-mail: hoh.boonpeng@gmail.com

\begin{abstract}
Obtaining sustainable source of cells or DNA from a single individual has always been a constraint in biomedical research. Generation of lymphoblastoid cell lines (LCLs) as a surrogate for replacement of isolated peripheral blood mononuclear cells (PBMCs) has substantially accelerated the process of biological investigations. LCLs can be established by transfection of $B$ lymphocytes from peripheral blood with Epstein Barr Virus (EBV), bearing minor genetic and phenotypic alterations. Here we report the generation of LCLs for the indigenous population (Orang Asli) from Peninsular Malaysia. The establishment of cell line is crucial for such isolated populations since the population size is small and sample collections are often challenging. We applied an alternative approach in isolation of PBMCs before proceeding to EBV transfection of Orang Asli samples, of which the BD Vacutainer CPT tubes were used to replace the conventional protocol such as Ficoll-paque or histopaque. We called this approach the "modified method of CPT" (MMC). A total of 59 out of the 64 samples (92\%) of Orang Asli were successfully transformed into LCLs by transfecting with EBV supernatant in a single attempt. To verify the success of LCLs transformation and confirm the presence of the human DNA, FCGR3B gene copy number variations of the DNA extracted from the LCLs were typed using Paralogue ratio test-restriction enzyme digest variant ratio (PRT-REDVR) analysis. The genotype results were compared between the DNA obtained from the LCLs and the original PBMCs from the identical individuals, and results revealed $100 \%$ concordance rate. The success of the transformation for LCL for the indigenous populations will eventually allow a more comprehensive and advanced biomedical research to be carried out in the next future without the exhaustion of the biomaterials.
\end{abstract}

\section{Keywords}

Modified method of CPT, Peripheral blood mononuclear cell, Lymphoblastoid cell line, Copy number variation, FCGR3B, Paralogue ratio test-restriction enzyme digest variant ratio (PRTREDVR)

\section{Introduction}

Orang Asli is a generic Malaysian term used officially to name the indigenous people of Peninsular Malaysia. They are believed to be the earliest populations that inhabited in Peninsular Malaysia, dated as early as 60,000 years ago $[1,2]$. Orang Asli represents only $0.5 \%$ of the total Malaysian population and is classified into three major tribes, namely Negrito, Senoi and Proto Malay [3].

Many of these Orang Asli tribes are undergoing drastic transformation of their lifestyle due to urbanization. On a separate note, some tribes for examples the Negritos, have been experiencing isolation and inbreeding resulted a smaller gene pool and population size $[2,4]$. Therefore they are thought to be an ideal model for the population genetic studies and mapping for complex diseases due to the fact that they are less admixed, less exposed to massive environmental changes and long period of isolation $[5,6]$. However, accessing the Negrito populations and obtaining sufficient biomaterials for any biomedical related research has been a major hindrance. Thus establishing the immortalized lymphoblastoid cell lines (LCLs) is of crucial to provide infinite resources of Orang Asli population such as Negritos for future sustainable genomic studies.

LCL is not only capable to extend the proliferation to avoid the exhaustion of storage of precious DNA samples thus minimizes the need of resampling, but also it possesses identical genotypes and expression to their parental cells. Therefore it has been widely used as the resources in many biomedical studies, ranging from gene expression and functionality studies, proteomics and metabolomics, mutational analysis, to the population based genomic studies including Human Genome Diversity Project, HapMap and 1000 Genome Project [7-21].

We report in this paper the generation of the immortalized LCL for the Orang Asli population from Peninsular Malaysia using the modified method called MMC and subsequently verified the integrity of genomic DNA extracted from the immortalized LCL samples by typing the FCGR3B copy number variation.

\section{Materials and Methods}

\section{Sample recruitment}

This study was approved by the Research and Ethics Committee of Universiti Teknologi MARA [Ref no: 600-RMI (5/1/6)], and

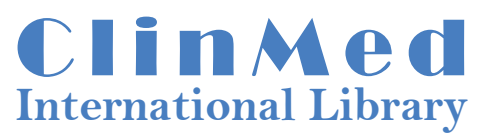
International Library

Citation: Yusof MH, Othman SIT, Mokhtar SS, Yunus Y, Aziz ATA, et al. (2016) Generation of Epstein-Barr Virus Immortalized-B Lymphocytes Cell Line of Orang Asli. J Genet Genome Res 3:028

Received: July 16, 2016: Accepted: September 21, 2016: Published: September 26, 2016 Copyright: @ 2016 Yusof MH, et al. This is an open-access article distributed under the terms of the Creative Commons Attribution License, which permits unrestricted use, distribution, and reproduction in any medium, provided the original author and source are credited. 
Table 1: Sample recruitment of Orang Asli in this study. Samples were collected from numerous locations at the district of Gua Musang, located at the north-east of Peninsular Malaysia. Bateq and Mendriq are the sub-tribe of Negritol; whilst the Temiar is a sub-tribe of Senoi.

\begin{tabular}{|l|l|l|l|l|}
\hline Tribe & Location & \multicolumn{2}{|l|}{ Gender } & Total \\
\cline { 3 - 4 } & & Male & Female & \\
\hline Bateq & Sg Aring & 10 & 3 & 13 \\
\hline Bateq & Pos Lebir & 13 & 6 & 19 \\
\hline Mendriq & Kuala Lah & 11 & 12 & 23 \\
\hline Temiar & Kuala Lah & 6 & 3 & 9 \\
\hline & Grand total & $40(62.5 \%)$ & $24(37.5 \%)$ & $64(100 \%)$ \\
\hline
\end{tabular}

Department of Orang Asli Development (JAKOA) [Ref no: JHEOA. PP.30.052.Jld 5(17)]. The details of recruited samples are shown in table 1. The Orang Asli samples were collected from Gua Musang, Kelantan, located at the northern east of Peninsular Malaysia. Prior sample collection, the headmen of the tribes or the community members were first consulted in a customary courtesy visit and their permission were obtained. During sampling, all participants were interviewed and written informed consent was obtained. Interview was conducted in Malay language and witnessed by an officer from JAKOA. Only participants above 18 years old who gave consent were recruited in this study. The samples consisted of both males and females from Negrito sub-tribes. A total of $6 \mathrm{ml}$ of peripheral blood (PB) was withdrawn from the 64 volunteers by using acid-citratedextrose (ACD) tube (BD vacutainer) and the samples were kept in Styrofoam storage box and kept at room temperature for further action.

\section{Media preparation}

Complete culture media consisting RPMI 1640 (Gibco), 1\% penicillin/streptomycin (10,000 U/mL) (Gibco) and 10\% of FBS (namely CM1) was used for culturing B95-8 cell line and the complete media consisting $20 \%$ of FBS (namely CM2) was used for protocol in cell transfection. Freezing media consisting of $90 \%$ FBS and $10 \%$ Dimethyl sulfoxide, (DMSO) namely FM was used to cryopreserve live cells.

\section{Peripheral blood mononuclear cell (PBMC) separation}

We modified the sample isolation method by using the ACD tubes which prolonged the period of preservation especially for remote area sample collection, often without proper storage equipment for many days. PBMCs isolation was conducted using strict aseptic technique using CPT tube that reduced isolation steps greatly as compared to gradient density method using conventional protocol such as Ficollpaque or histopaque solution. We called this alternative approach the "modified method of CPT" (MMC). Firstly, the collected blood samples in ACD tube was transferred into CPT tubes (BD vacutainer') as soon as we were back in the laboratory. The isolation was done by centrifuging (Multifuge $3 \mathrm{~s}$-r, Heraeus) the CPT tubes at $1,750 \times \mathrm{g}$ for $30 \mathrm{~min}$ at room temperature. Then, the buffy coat (consisted mononuclear cell or PBMC) from CPT was transferred into a $15 \mathrm{ml}$ falcon tube. The PBMCs were washed twice with the Phosphate Buffer Saline (PBS) (Sigma) and centrifuged for $300 \times g$ for $10 \mathrm{~min}$ at room temperature. The supernatant was discarded and the pellet was stored in a cryopreserved vial (Greiner Bio-one) in FM media. The cryopreserved vial was stored in $-152^{\circ} \mathrm{C}$ freezer for longterm storage after performing differential tryphan blue for PBMCs recovery analysis.

\section{EBV stock preparation}

The culturing method of B95-8 cell line was adapted from Hui-Yuen, et al. (2011) [22]. B95-8 cells (ECACC Lot \# 09H030) were cultured in $5 \mathrm{ml} \mathrm{CM} 1$ media in a T25 tissue culture flask at 5 $\times 10^{5}$ cells $/ \mathrm{ml}$ seeding density. The flask was incubated at $37^{\circ} \mathrm{C}$ in the presence of $5 \% \mathrm{CO}_{2}$. After 72 hours, all B95-8 cells in the flask were collected by using $10 \mathrm{ml}$ of sterile serological pipettes (Greiner Bio-one) and transferred into $15 \mathrm{ml}$ falcon tubes. The cell was then centrifuged at $300 \times \mathrm{g}$ for $10 \mathrm{~min}$ at room temperature and the pellet was resuspended in fresh $10 \mathrm{ml}$ of CM1 at $1 \times 10^{6}$ cells/ml cell density.
Table 2: The formulation and counting of PBMC for EBV transfection per well.

\begin{tabular}{|l|l|l|l|l|}
\hline $\begin{array}{l}\text { PBMC Count } \\
\text { (cell/ml) }\end{array}$ & $\begin{array}{l}\text { Complete } \\
\text { Media, CM2 } \\
(\mathbf{m l})\end{array}$ & $\begin{array}{l}\text { EBV } \\
\text { supernatant } \mathbf{( m l )}\end{array}$ & $\begin{array}{l}\text { Total } \\
\text { volume } \\
\text { (ml) }\end{array}$ & $\begin{array}{l}\text { Cyclosporin-A } \\
\mathbf{( 1 ~} \mathbf{~ m g} / \mathbf{m l})\end{array}$ \\
\hline $1.0 \times 10^{6}$ & 0.4 & 0.2 & 0.6 & $2.4 \mu \mathrm{l} /$ well \\
\hline
\end{tabular}

The cells were transferred into a $25 \mathrm{~cm}^{2}$ tissue culture flask to induce virus production.

B95-8 cell line at $1 \times 10^{6}$ cells $/ \mathrm{ml}$ was stimulated with $40 \mathrm{ng} / \mathrm{ml}$ tetradecanoylphorbol acetate (TPA) (Sigma) for 1 hour in a $\mathrm{CO}_{2}$ incubator to produce EBV supernatant. After 1 hour, the cells in the flask were collected by using $10 \mathrm{ml}$ of sterile serological pipettes and transferred into $15 \mathrm{ml}$ Falcon tubes. Cells were washed three times with PBS to remove TPA. Cells were re-suspended in $5 \mathrm{ml}$ of CM1 and placed the flask in a $\mathrm{CO}_{2}$ incubator for 96 hours. After that, the cell was centrifuged at $300 \times \mathrm{g}$ for $10 \mathrm{~min}$ at $4^{\circ} \mathrm{C}$ to separate $\mathrm{EBV}$ particle from B95-8 cells. The supernatant was filtered through a 0.20 -micron filter (Sigma) to unsure no remaining of B95-8 marmoset cells was mixed with EBV supernatant. EBV supernatant was aliquot in $1 \mathrm{ml}$ cryopreservation vials and labeled appropriately. The cryopreserved vial can be stored at $-80^{\circ} \mathrm{C}$ for maximum of one year.

\section{Generation of lymphoblastoid cell line}

This protocol was carried out according to Danjoh, et al. (2012) [23]. The mixture of the PBMC in CM2 was prepared according to table 2 and cultured into 24 -well plate after evenly mixed by eight figure swirling motion. The plate was placed in $5 \%$ $\mathrm{CO}_{2}$ incubator (Galaxy R) at $37^{\circ} \mathrm{C}$ for seven days without disturb or any manipulation. On day seven, $0.25 \mathrm{ml}$ of complete media (CM2) was added and the culture was incubated for another seven days where the cell showed rosette morphology and cell clumping, indicating that the cells have reached the stage of exponential proliferation hence can be transferred into $25 \mathrm{~cm}^{2}$ T-flask for further cell expansion. Then $1 \mathrm{ml}$ of LCLs from 24 well plates was transferred into a $25 \mathrm{~cm}^{2}$ T-flask. About $4 \mathrm{ml}$ of the CM2 was added into the flask and kept upright in the incubator with $5 \%$ $\mathrm{CO}_{2}$ at $37^{\circ} \mathrm{C}$. The feeding procedure for LCLs in the $25 \mathrm{~cm}^{2} \mathrm{~T}$-flask was continued every 5-7 days with the addition of $2 \mathrm{ml}$ of CM2. This culture condition is biased towards B cells proliferation and limited the growth of other cells. After about 1 month, the LCLs are ready to be prepared for DNA extraction using Qiagen Mini Blood Extraction Kit (Qiagen, Hilden, Germany) according to the manufacturer's protocol or were frozen in cryopreserved for future usage.

\section{Validation of the extracted genomic DNA with FCGR3B copy number variation genotyping}

DNA was extracted on 14 identical samples of both peripheral blood (PB) and LCLs sample and the quality and purity of DNA extracted from both peripheral blood and LCL were measured by using nanospectrophotometer (Nanodrop, ND-1000). Then, FCGR3B was genotyped by using the paralogue ratio test-restriction enzyme digest variant ratio (PRT-REDVR) technique. The PRT-REDVR assays were described according to Hollox, et al. (2009) [24]. The PRT analysis for copy number $(\mathrm{CN})$ call was performed in combination with the REDVR analysis, using a maximum likelihood approach [25].

\section{Results}

\section{Sample recruitment and $\mathrm{PBMC}$ isolation}

Peripheral blood samples were collected in ACD tubes and kept for 3 days at the sampling locations without proper storage equipment. The modified approaches were applied and demonstrated a better PBMCs separation, with minimal red blood cells (RBC) contamination. The cell count viability for Orang Asli PBMC's sample ranged from $30-91 \%$ cells $/ \mathrm{ml}$ for all 64 samples, with the mean \pm standard error of mean (SEM) of $7.8 \pm 0.14 \times 10^{6} \mathrm{cells} / \mathrm{ml}$ of viable cell with more than $75 \%$ of the PBMCs samples show high cell viability ranging from $70-91 \%$. 

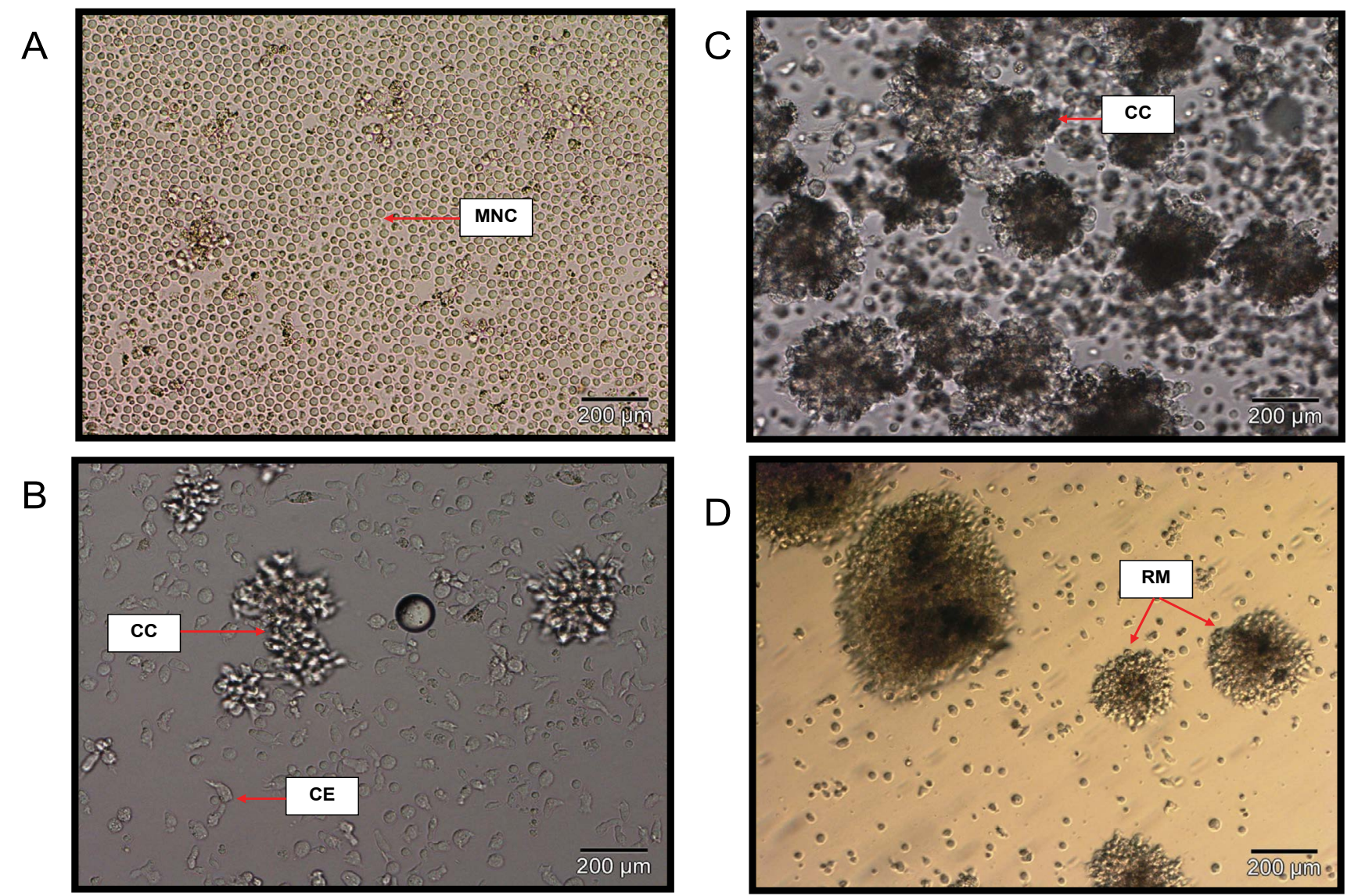

Figure 1: Visualization of cell before and after transformation by light phase inverted microscope; $(A)$ PBMC before transformation $(20 \times$ magnification); $(B)$ one week post infection (20 × magnification); (C) two week post infection $(20 \times$ magnification) magnification; (D) four week post infection in T25 flask (10 $\times$ magnification).

MNC: mononuclear cell, CE: cell elongated, CC: cell clumping, RM: rosette shape morphology.

Table 3: Comparison of copy number (CN) calls for FCGR3B on the genomic DNA extracted from lymphoblastoid cell line and peripheral blood using PRTREDVR assay. CNV typing revealed $100 \%$ concordance rate. PB: peripheral blood; LCL: lymphoblastoid cell line.

\begin{tabular}{|l|l|l|}
\hline Sample ID & FCGR3B CN for PB & FCGR3B CN for LCL \\
\hline K11 & 2.0 & 2.0 \\
\hline K12 & 2.0 & 2.0 \\
\hline K40 & 2.0 & 2.0 \\
\hline K5 & 2.0 & 2.0 \\
\hline K7 & 2.0 & 2.0 \\
\hline K9 & 2.0 & 2.0 \\
\hline P11 & 2.0 & 2.0 \\
\hline P12 & 2.0 & 2.0 \\
\hline P19 & 2.0 & 2.0 \\
\hline P22 & 4.0 & 4.0 \\
\hline P23 & 3.0 & 3.0 \\
\hline S10 & 2.0 & 2.0 \\
\hline S2 & 2.0 & 2.0 \\
\hline S3 & 2.0 & 2.0 \\
\hline
\end{tabular}

\section{Immortalization of PBMC of Orang Asli samples}

A total of 59 samples were successfully transformed. The success of the PBMCs transformation was based on one attempt; however five of Orang Asli PBMC samples failed to transform into LCLs even after repetitive attempts, thus demonstrated $92.2 \%$ success rate for the establishment of LCLs. The failure was caused by the low quality and viability of PBMC due to error during sampling trip. The time for EBV-B lymphocyte to show sign of success transformation of Orang Asli samples ranged from 7-14 days. The overall results suggested that the modified method of transforming PBMCs into LCLs in this study was reliable considering the success rate of transformation.

The success of LCLs immortalization was confirmed by morphological changes including cells clumping and formation of rosette shape (Figure 1). The cell elongation, cell trajectory, big clumping and rosette morphology of the cells observed indicated that the cell was successfully transformed. After 6 weeks, the bigger clumping of the cell can be seen by naked eyes and usually at this stage the LCLs were ready for DNA extraction or to be cryopreserved for future study.

\section{Verification of the integrity of DNA extracted from LCL using PRT-REDVR}

PRT-REDVR of FCGR3B CNV was performed on both DNA extracted from identical samples of LCL and peripheral blood samples. Comparison of the copy number calls between LCL and peripheral blood on 14 identical samples revealed $100 \%$ concordance of copy number calls, suggesting the success of DNA extraction from the LCL transformation with appropriate integrity (Table 3).

\section{Discussion}

\section{Isolation of PBMC by modified method of CPT (MMC)}

The efficiency of establishing B-LCLs from freshly obtained blood samples are often great, however long storage duration in compromised with high temperature during sample collection in rural area is still the biggest hindrance for EBV transfection success story $[23,26]$. The usage of acid-citrate-dextrose (ACD) tube consisting of trisodium citrate, citric acid and dextrose solution which serve as an anticoagulant, cell preservative and nutrient to the cell culture allows better survival of cell during storage by enhancing the vitality and recovery of the leukocytes for up to five days after blood collection [27,28]. Thus, it is suitable for sample collection in rural area as demonstrated in this study where ACD tube has shown a better outcome for prolonged blood sample collection specifically in remote area compared to the EDTA and sodium heparin tubes [29]. Nonetheless the vitality and recovery of the leukocytes will decrease drastically once all nutrients in the tube are consumed by cellular components. 
In this study we used the cell preparation tube (CPT) containing citrate anticoagulant with a gradient density Ficoll $^{\mathrm{Tw}} \mathrm{Hypaque}^{\mathrm{nt}}$ fluid and polyester gel barrier which permits cell separation from whole blood being conducted in a single centrifugation step with minimal erythrocytes contamination during PBMCs fractionization step. Blood samples should be centrifuged or separated within 2 hours of blood drawing maintain great cell viability. Mononuclear cell recovery decreases with the increased of time delay before centrifugation, falling to $40-80 \%$ of PBMC recovery at 12 to 24 hours respectively.

Traditionally Ficoll-Paque is placed at the bottom of a conical tube, and blood is then slowly layered above Ficoll-Paque. After a minimum of 30 minutes uninterrupted centrifugation, the following layers will be visible in the conical tube, from top to bottom: (i) Plasma and other constituents, (ii) A layer of mononuclear cells called buffy coat (PBMC), (iii) Ficoll-Paque, and (iv) Erythrocytes and granulocytes which should be presented in pellet form. This separation allows efficient harvest of PBMC's. Point to note that, this technique requires high skilled operator especially when layering the blood above the Ficoll-Paque solution. Mistakes normally occur during this step which could cause damage to the blood sample. Furthermore, additional step where dilution of blood with phosphate buffer saline is needed to perform this technique thus making this technique lengthy and tedious. Our protocol offers more convenient and less exhausting steps by eliminating blood dilution and FicollPaque layering steps during PBMC isolation. This is particularly convenient when involving large number of sampling in remote area with minimal storage equipment by effectively preserves high quality isolated cells even after a standard 48 hours cell isolation window period.

\section{The generation of LCLs for Orang Asli negrito}

Approaches for generation of EBV transformed B lymphocyte cell lines have been established since the last 30 years; whilst generation of the LCLs for numerous indigenous populations if the world has been previously reported. Danjoh, et al. (2011) [21] was one of the groups that established LCL on the indigenous ethnic population of South America and deposited in Japan (Sonoda-Tajima Cell Collection). In our study, LCL from 59 Orang Asli samples have been established, consisting of Mendriq $(\mathrm{n}=23)$ and Bateq $(\mathrm{n}=27)$ from Negrito tribe and some sample from Temiar (a Senoi sub-tribe) $(\mathrm{N}=9)$. The success rate of 92.2 of LCL immortalization is comparable with other studies conducted in Japan and United State of America ranging from $90-94 \%[23,27]$. Several factors could be attributed to the failure of the transformation of LCL in this study: (i) Compromised sample collection tubes leading to contamination of PBMC; (ii) Low seeding density at initial culture stage; (iii) Long period of cryopreserved PBMCs before EBV transfection; (iv) Low number of PBMCs per sample collected; (v) High percentage of non-viable cells during proliferation stage which contribute to cytotoxic culture condition; and (vi) Suboptimal seeding density of PBMCs after EBV infection and EBV titre.

Our study has successfully demonstrated the transformation of EBV-B lymphocyte by discovering the formation of rosette shape morphology in culture plate as established by previous studies $[7,30]$. The average time taken for the sign has been detected as early as 7-14 days, which in line with previous studies $[27,28]$. Several approaches can be applied to increase the success rate of EBV-B lymphocytes such as increasing the number of PBMCs [31]. EBV titer, viability of PBMCs, or the introductions of feeder cell, are among factors to increase the success of LCL generation. In this study we eliminated the cytotoxic effect of $\mathrm{T}$ cell by suppress the activity of $\mathrm{T}$ cell using cyclosporine A as suggested by previous study [21,23]. FK 506 also known as Tacrolimus also can be used to eliminate the activity of $\mathrm{T}$ cell activation since this drug has similar function as cyclosporine A [22].

\section{Consistency of using LCL for PRT-RDVR assay for FCGR3B CNV typing}

Multiallelic the copy number variation of FCGR3B was significantly associated with a number of systemic autoimmune and infectious diseases [32-36]. Therefore on top of confirming the presence of the genomic DNA of the LCL generated, it is crucial to understand the nature of the gene copy number variation of this gene in immortalized LCL before a thorough investigation is carried out. PRT produces the sum of the copy number calls for FCGR3A and FCGR3B genes whilst the REDVR estimates the copy numbers of FCGR $3 A$ and based on the ratio determined. PRT produces the sum of the copy number calls for FCGR3A and FCGR3B genes whilst the REDVR estimates the copy numbers of FCGR3A and FCGR3B based on the ratio determined [32]. LCLs are known to exist in two distinguishable forms namely, pre- and post-immortal. In the pre-immortal stage cells proliferate actively and maintain a diploid karyotype. These cells are non-tumorigenic and stable genetically and phenotypically $[37,30]$.

In our study, the comparison of the copy number calls for FCGR3B between LCLs and peripheral blood revealed 100\% concordance of copy number calls which prove the stability and integrity of genomic material isolated from the transformed LCLs and suitable to replace the limited peripheral blood.

\section{Summary}

We have successfully generated the lymphoblastoid cell lines of the Orang Asli samples using an alternative approach, and have further verified the integrity of the genomic DNA by characterizing the FCGR3B copy number distribution among Orang Asli Negrito using LCLs as starting biomaterial. LCL has been used for last few decades and their utility is gradually being recognized as an excellent surrogate for limited sources of isolated lymphocytes. However, one has to be aware of the few potential inherent limitations of LCLs use, which include potential chromosomal aberration in the transfected B-cells [38-40]. The generation of LCL for indigenous population will allow more comprehensive advanced investigations to be carried out on these isolated populations in the next future without exhaustion of the biomaterials.

\section{Acknowledgement}

This study was approved by the Research and Ethics Committee of Universiti Teknologi MARA [Ref no: 600-RMI (5/1/6)], and Department of Orang Asli Development (JHEOA) [Ref no: JHEOA. PP.30.052.Jld 5(17)]. This study is supported by the grant MOSTI (100-RMI/BIOTEK 16/6/2B (1/2011)). We thank the Institute of Medical Molecular Biotechnology (IMMB), Faculty of Medicine, Universiti Teknologi MARA (UiTM), Sungai Buloh Campus, Malaysia for the support throughout the experiments. We would also wish to express our gratitude to all volunteers who participated to this study and JAKOA for their support during the sampling collections.

\section{References}

1. HUGO Pan-Asian SNP Consortium, Abdulla MA, Ahmed I, Assawamakin A Bhak J, et al. (2009) Mapping human genetic diversity in Asia. Science 326: 1541-1545.

2. Deng L, Hoh BP, Lu D, Fu R, Phipps ME, et al. (2014) The population genomic landscape of human genetic structure, admixture history and local adaptation in Peninsular Malaysia. Hum Genet 133:1169-1185.

3. JHEOA (2006) Annual report of Department of Orang Asli Affairs 2006. Kuala Lumpur: JHEOA.

4. JHEOA (2010) Pecahan Penduduk Orang Asli Mengikut Kumpulan Kaum Dan Etnik Bagi Tahun. Kuala Lumpur: JHEOA.

5. Macaulay V, Hill C, Achilli A, Rengo C, Calrke D, et al. (2005) Single, rapid coastal settlement of Asia revealed by analysis of complete mithochondrial genomes. Science 308: 1034-1036.

6. Stock JT (2013) The Skeletal Phenotype of "Negritos" from the Andaman Islands and Philippines Relative to Global Variation among Hunter-Gatherers. Human Biology 85: 69-94.

7. Neitzel H (1986) A routine method for the establishment of permanent growing lymphoblastoid cell lines. Hum Genet 73: 320-326.

8. Okubo M, Tsurukubo Y, Higaki T, Kawabe T, Goto M, et al. (2001) Clonal chromosomal aberrations accompanied by strong telomerase activity in immortalization of human B-lymphoblastoid cell lines transformed by EpsteinBarr virus. Cancer Genetic Cytogenetic 129: 30-34. 
9. Herbeck JT, Gottlieb GS, Wong K, Detels R, Phair JP, et al. (2009) Fidelity of SNP Array Genotyping Using Epstein Barr Virus-Transformed B-Lymphocyte Cell Lines: Implications for Genome-Wide Association Studies. PLoS ONE 4: e6915.

10. deMello AS, Mendes FB, Michelin-Tireli, K, Camelier MV, Coelho JC (2011) Effect of One Year of Cryopreservation on the Activity of Lysosomal Hydrolases from EBV-Transformed Lymphocytes. Journal of Biomedicine and Biotechnology 132581: 5.

11. Londin ER, Keller MA, D' Andrea MR, Delgrosso K, Ertel A, et al. (2011) Whole-Exome sequencing of DNA from peripheral blood mononuclear cells (PBMC) and EBV-transformed lymphocytes from the same donor. BMC Genomics 12: 464.

12. Mei YP, Zhu XF, Zhou JM, Huang H, Deng R, et al. (2006) siRNA targeting LMP1-induced apoptosis in EBV-positive lymphoma cells is associated with inhibition of telomerase activity and expression. Cancer Letters 232: 189-198.

13. Bernacki SH, Beck JC, Muralidharan K, Schaefer FV, Shrimpton AE, et al. (2005) Characterization of publicly available lymphoblastoid cell lines for disease-associated mutations in 11 genes. Clinical Chemistry 51: 2156-2159.

14. Sie L, Loong S, Tan EK (2009) Utility of lymphoblastoid cell lines. Journal of Neuroscience Research 87: 1953-1959.

15. Toda T, Sugimoto M (2003) Proteome analysis of Epstein-Barr virustransformed B-lymphoblasts and the proteome database. Journal of Chromatography. B Analytical Technology Biomedical Life Sciences 787 197-206

16. Wishart DS, Tzur D, Knox C, Eisner R, Guo AC, et al. (2007) HMDB: the Human Metabolome Database. Nucleic Acids Res 35: D521-D526.

17. Wu RM, Bounds R, Lincoln S, Hulihan M, Lin CH, et al. (2005) Parkin mutations and early-onset Parkinsonism in a Taiwanese cohort. Arch Neurology 62: 82-87.

18. Mayeux R (2006) P1-279 Familial Alzheimer's disease: The NIA-LOAD Study. Alzheimers Dementia 2: S178-S179.

19. Meschia JF, Brown RD Jr, Brott TG, Chukwudelunzu FE, Hardy J, et al (2002) The Sibling With Ischemic Stroke Study (SWISS) Protocol. BMC Medical Genetics 3:1.

20. Hu VW, Frank BC, Heine S, Lee NH, Quackenbush J (2006) Gene expression profiling of lymphoblastoid cell lines from monozygotic twins discordant in severity of autism reveals differential regulation of neurologically relevant genes. BMC Genomics 7: 118.

21. Danjoh I, Saijo K, Hiroyama T, Nakamura Y (2011) The Sonoda-Tajima Cell Collection: A Human Genetics Research Resource with Emphasis on South American Indigenous Populations. Genome Biol Evol 3: 272-283.

22. Hui-Yuen J, McAllister S, Koganti S, Hill E, Bhaduri-McIntosh S (2011) Establishment of Epstein-Barr Virus Growth-transformed Lymphoblastoid Cell Lines. J Vis Exp 57: 3321.

23. Danjoh I, Sone H, Shirota R, Hiroyama T, Nakamura Y (2012) Development of a robust method for establishing $B$ cell lines using Epstein-Barr Virus. In Vitro Cellular Dev Biol Anim 48: 393-402.

24. Hollox EJ, Detering J, Dehnugara T (2009) An integrated approach for measuring copy number variation at the FcGR3B (CD16) locus. Hum Mutat 30: $477-484$
25. Umi Shakina H, Umairah M, Machado LR, Abu Thalhah AZ, Rafidah Hanim S, et al. (2015) A comparison of assays for accurate copy number measurement of the low-affinity Fc gamma receptor genes FCGR3A and FCGR3B. PLoS One 10: e0116791.

26. Oh HM, Oh JM, Choi SC, Kim SW, Han WC, et al. (2003) An efficient method for the rapid establishment of Epstein-Barr virus immortalization of human $B$ lymphocytes. Cell Prolif 36: 191-197.

27. Beck JC, Beiswanger CM, John EM, Satariano E, West D (2001) Successfu transformation of cryopreserved lymphocyte: A resource for epidemiological studies. Cancer Epidemiol Biomarkers Prev 10: 551-554.

28. Lam KMC, Crawford DH (1995) Method for Generation of Human B Lymphoblastoid Cell Lines Using Epstein-Barr virus. Method in Cell Science 17: $67-74$.

29. Fiscus SA, Chakraborty H, Shepard R, Goodman M (2000) Comparison of blood collected in acid-citrate-dextrose and EDTA for use in human immunodeficiency virus peripheral blood mononuclear cell cultures. Journal of Clinical Microbiology 38: 858-860.

30. Hussain T, Mulherkar R (2012) Lymphoblastoid Cell lines: a Continuous in Vitro Source of Cells to Study Carcinogen Sensitivity and DNA Repair. Int $J$ Mol Cell Med 1: 75-87.

31. Wall FE, Henkel RD, Stern MP, Jenson HB, Moyer MP (1995) An Efficient Method for Routine Epstein - Barr virus Immortalization of Human B Lymphocytes. In Vitro Cell Dev Biol Anim 31: 156-159.

32. Aitman TJ, Dong R, Vyse TJ, Norsworthy PJ, Johnson MD, et al. (2006) Copy number polymorphism in Fcgr3 predisposes to glomerulonephritis in rats and humans. Nature 439: 851-855.

33. Fanciulli M, Norsworthy PJ, Petretto E, Dong R, Harper L, et al. (2007) FCGR3B copy number variation is associated with susceptibility to systemic but not organ-specific, autoimmunity. Nature Genet 39: 721-723.

34. Willcocks LC, Lyons PA, Clatworthy MR, Robinson JI, Yang W, et al (2008) Copy number of FCGR3B, which is associated with systemic lupus erythematosus, correlates with protein expression and immune complex uptake. J Exp Med 205: 1573-1582.

35. McKinney C, Fanciulli M, Merriman ME, Phipps-Green A, Alizadeh B Z, et al. (2010) Association of variation in Fcy receptor 3B gene copy number with rheumatoid arthritis in Caucasian samples. Ann Rheum Dis 69: 1711-1716.

36. Machado LR, Bowdrey J, Ngaimisi E, Habtewold A, Minzi O, et al. (2013) Copy number variation of Fc gamma receptor genes in HIV-infected and HIVtuberculosis co-infected individuals in Sub-Saharan Africa. PLoS One 8: e78165.

37. Shirley MD, Baugher JD, Stevens EL, Tang Z, Gerry N, et al. (2012) Chromosomal variation in lymphoblastoid cell lines. Hum Mutat 33: 1075-1086.

38. Trenz K, Landgraf J, Speit G (2002) Mutagen sensitivity of human lymphoblastoid cells with a BRCA1 mutation. Breast Cancer Res. Treat 2463: 1-11.

39. Baeyens A, Thierens H, Vandenbulcke K, De Ridder L, Vral A (2004) The use of EBV-transformed cell lines of breast cancer patients to measure chromosomal radiosensitivity. Mutagenesis 19: 285-290.

40. Zijno A, Porcedda P, Saini F, Allione A, Garofalo B, et al. (2010) Unsuitability of lymphoblastoid cell lines as surrogate of cryopreserved isolated lymphocytes for the analysis of DNA double-strand break repair activity. Mutat Res 684: 98-105. 